\title{
EFFECT OF FEEDING DIFFERENT LEVELS OF SYNTHETIC LIQUID MILK ON THE PRODUCTIVE PERFORMANCE OF SUCKLING BUFFALO CALVES. 2- AT POSTWEANING
}

\author{
G.F. Shahin; Mona E. Farag; S.A. Ebrahim and M.A. Abd El-Latif. \\ Animal Production Research Institute, Ministry of Agriculture, Dokki, Giza, Egypt.
}

\section{SUMMARY}

$\mathrm{T}$ This study aimed to evaluate the effect of using synthetic liquid milk (LM) in combination with whole cow milk (WCM) in replacing of the whole buffalo milk (WBM) during pre-weaning on growth performance of buffalo calves during post weaning. Twelve newly born buffalo calves ( 9 males and 3 females) were divided randomly according to their body weight and sex into three similar groups with average body weight $42.13 \mathrm{~kg}$ at the beginning of the first part of this study which published by Mona $e t$ al. (2014). Mean live body weight at the beginning of the $2^{\text {nd }}$ experiment was $100.51,98.16$ and $92.63 \mathrm{~kg}$ and aged 98, 105 and 84 days at weaning of treatments G1: 100\% of allowances from WBM (control), G2: 75\% of allowances from WCM plus 25\% LM, and G3: $50 \%$ of allowances from WCM plus 50\% LM had given during pre-weaning period in the first experimental. Over the $2^{\text {nd }}$ experiment all animal groups were fed according to Kearl (1982), concentrate feed mixture (CFM 1) (16\% CP and 70\% TDN), berseem hay and rice straw (70: $25: 5 \%$ ) from weaning weight up to $150 \mathrm{~kg}$ of live body weight ( 1 st period) and fed concentrate fed mixture (CFM 2) (14\% CP and65\% TDN), berseem hay and rice straw (60: $25: 15 \%)$ from $150 \mathrm{~kg}$ up to $250 \mathrm{~kg}$ of live body weight $\left(2^{\text {nd }}\right.$ period).Results indicated that during the $1^{\text {st }}$ period of post weaning, G3 recorded significant higher $(\mathrm{P}<0.05)$ daily feed intake as $\mathrm{DMI}$ and TDN, digestibility of DM and CP, total gain and daily gain than those of other treatments. While those fed G3 or (G2) recorded significant higher CF digestibility than those in (G1). On the other hand, G2 showed the longest period at age during the first period. Concerning the results during the $2^{\text {nd }}$ period at post weaning, there were no significant differences among treatments respecting daily feed intake, feed conversion, digestibility coefficients, live body weight and daily gain. Also, calves in G3 showed the shortest period of age in second period, while the animals fed $\mathrm{G} 1$ showed that the highest $(\mathrm{P}<0.05)$ values of total gain, and the lowest one was recorded for $\mathrm{G} 2$ ration. Data of economic efficiency during overall experimental period indicated that the most expensive daily feeding cost was recorded for group G3 or G1, compared with G2. While, price of daily weight gain of calves fed G3 or G1 were higher than those of G2 group. The same trend respecting relative return and economic efficiency was found. The best relative return and economic efficiency were obtained by calves fed G3, followed by G1, while G2 recorded the lowest return and economic efficiency. This may help farmers to keep up and care of suckling buffalo calves and not sell them and such regime could help to alleviate the problem of milk and beef shortage in Egypt.

Keywords: Synthetic liquid milk during post weaning, buffalo calves, growth performance and feed conversion.

\section{INTRODUCTION}

The buffalo population in Egypt about 3.1 million heads (FAO, 1998) and contribute about $70 \%$ to domestic milk production (Nigm, 1996). Farmers used to sell males at 40 days of age or earlier to save milk to human consumption and increasing their income and avoid calf mortality.

The nutritional cost of milk production is high at all times of the year and this drain may interfere with the ability of farmers to the continuation of rearing suckling buffalo calves till weaning ( 3 months of age) on the WBM. However, several researchers have recognized that averages daily gain of calves at all times of the growing period is affected less by synthetic liquid milk (LM) compared with the whole cow milk (WCM) (Moms and Wilton, 1976) or by milk production up to peak lactation (Ansotegui, 1986).

Forage intake by nursing calves is influenced by amount of suckled milk (Baker and Barker, 1978) and by availability and quality of intake (Wright and Russel, 1987). The range of correlation between level of milk consumption and weight gain among calves varies from 0.4 to $0.88 \mathrm{~kg}$ (Totusek and Arnett, 1965; Wyatt et al., 1977). Few experiments have evaluated the performance by calves nursing controlled amounts of milk, while consuming forage, and the subsequent effect on the feedlot finishing phase. 


\section{Shahin et al.}

Abdalla et al. (1988) found that Holstein calves fed low-protein diet during early growth exhibited compensatory growth during the finishing period.

At a similar feeding rate, WM-fed calves receive much greater amounts of both protein and fat than MR-fed calves. Low supply of nutrients is one of the primary factors limiting the growth of MR-fed calves compared with WM-fed calves, although the quartic effect was significant, milk intake had no consistent effect on post-weaning ADG (Lynch et al., 1978). Furthermore, Kuehn et al. (1994) demonstrated a negative relationship between fat and protein content of MR and starter consumption by calves. However, increased intake of energy in calves before 2 mo of age showed no negative effects on subsequent milk production (Brown et al., 2005). Recently, Meyer et al. (2006a, b) demonstrated that elevated nutrient intake did not negatively affect mammary development in heifers. Furthermore, some fat deposition during the pre-weaning period can probably play a beneficial role to combat milk weaning stress in calves. We hypothesized that equalizing the gross composition of MR to WM may allow dairy calves fed MR to grow and perform similarly to the WM-fed calves.Therefore, the objectives of this study were to evaluate the effect of milk intake on forage intake, post-weaning growth, and body measurements and productive performance of male and female buffalo calves.

\section{MATERIALS AND METHODS}

\section{Treatments and management:}

This experiment was conducted to study the effect of feeding two levels of synthetic liquid milk (milk replacer) (LM) on growth performance at post-weaning period. Experiment was carried out at ElGemmeza Animal Production Research Station, Animal Production Research Institute, Agricultural Research Center. Nine male and three female of buffalo calves were separated from their mothers within $2 \mathrm{~h}$ of birth and weighed (means birth weight, $39.81 \mathrm{~kg})$. They were placed in an individual pens $(1.0 \times$ $1.5 \mathrm{~m}$ ) and fed colostrum at the rate of $10 \%$ of LBW twice daily for the first three days. All claves were fed whole buffalo milk (WBM) at the rate of $10 \%$ of LBW twice daily for seven days. Consecutively calves were divided depending on weight and six into three groups with average body weight $42.13 \mathrm{~kg}$ at the beginning of the first part of this study which published by Mona et al. (2014). The mean live body weight at the beginning of the $2^{\text {nd }}$ experiment were $100.51,98.16$ and $92.63 \mathrm{~kg}$ with age of 98,105 and 84 days (at weaning) for groups G1, G2 and G3, respectively, G1: 100\% of allowances from WBM (control), G2: $75 \%$ of allowances from WCM plus 25\% LM, and G3: $50 \%$ of allowances from WCM plus 50\% LM, respectively, during pre-weaning period was recorded throughout the first experimental.On the $2^{\text {nd }}$ experimental treatments, all young calves groups were fed according to Kearl, (1982), standard onCFM1 (16\% CP and TDN 70\%), berseem hay and rice straw (70: 25: 5\%) from weaning weight to 150 $\mathrm{kg}$ of live body weight ( $1^{\text {st }}$ period) and fed on other formula CFM2(14\% CP and TDN 65\%), berseem hay and rice straw (60: $25: 15 \%)$ from $150 \mathrm{~kg}$ to $250 \mathrm{~kg}$ of live body weight ( $2^{\text {nd }}$ period), (Table 1$)$. Minerals blocks and fresh water were available freely through the experimental periods. The CFM and roughage were offered twice daily at 7.0 a.m and 4.0 p.m. Daily feed intake was individually recorded, while live body weight of each calve was biweekly recorded before morning feeding and then total and average daily gain (ADG) was calculated. Feed allowance was adjusted biweekly according to the change in body weight. Feed consumption, growth, and health condition of calves were recorded over postweaning period.

\section{Sampling and Analysis}

Daily intakes of starter, CFM1, CFM2, BH, and rice straw were recorded throughout the experiment Representative samples of CFM, BH, rice straw, refusals and feces were analyzed for DM, CP, EE, CF and ash contents according to the A.O.A.C. (1995). The nitrogen free extract (NFE) was calculated. Chemical analysis of different feedstuffs and calculated composition of the experimental rations are presented in Table 2. Blood samples were taken from all experimental calves at the end of the $1^{\text {st }}$ and $2^{\text {nd }}$ period of the experiment, at three hours after morning feeding from the jugular vein into clean glass tubes and left at room temperature for 45-60 minutes, then centrifuged at 4000 r.p.m for 15 minutes. Blood serum was separated into clean dry glass vials and stored at $-20^{\circ} \mathrm{C}$ until analyses. Blood serum samples were analyzed for the following parameters: total protein (Henry, 1964), Albumin (Doumaset al., 1971), Serum urea (Patton and Crouch, 1977), Calcium (Saunders, 1970), In-organic phosphorus (Armstrong and Carr, 1964), Globulin was calculated by subtraction of serum albumin from total serum protein.

Six digestibility trials were conducted using all calves (male and female) in the experimental groups. The first three digestibility trials were carried out at the end of the $1^{\text {st }}$ period. The second three digestibility trials were conducted at the end of the $2^{\text {nd }}$ period. Fecal grape samples were taken from 
calves at three successive days. It was weighed fresh and $10 \mathrm{ml}$ of $10 \%$ sulfuric acid and $10 \mathrm{ml}$ of formalin were added to it for preservation then dried in an oven at $60^{\circ} \mathrm{C}$, for 24 hours. At the end of collection period, feces samples for each animal were ground, mixed well and kept in plastic bottles until analysis. The data were analyzed according to statistical analysis system, (SAS) User's Guide, (1998). Differences among means was carried out by using Duncan multiple range tests (1955).

Table (1). Ingredients of CFM fed to Buffalocalves (as DM basis \%).

\begin{tabular}{|c|c|c|}
\hline Ingredient $\%$ of $\mathrm{DM}$ & CFM1 & CFM2 \\
\hline Corn & 46 & 35 \\
\hline Wheat bran & 15 & 32 \\
\hline Soybean meal & 19 & 10 \\
\hline Rice bran extracted & 13 & 18 \\
\hline Molasses & 4 & - \\
\hline Dicalcium phosphate & 1.5 & 3 \\
\hline Salt & 0.5 & 1 \\
\hline minerals premix $^{1}$ & 0.5 & 0.5 \\
\hline Vitamin premix ${ }^{2}$ & 0.5 & 0.5 \\
\hline \multicolumn{3}{|c|}{$\begin{array}{l}{ }^{1} \text { Provided (DM basis): } 5 \mathrm{mg} / \mathrm{kg} \text { of Co, } 25 \mathrm{mg} / \mathrm{kg} \text { of } \mathrm{Cu}, 0.01 \% \mathrm{I}, 400 \mathrm{mg} / \mathrm{kg} \text { of } \mathrm{Fe}, 1 \% \mathrm{~K}, 0.60 \% \mathrm{Na}, 0.15 \% \mathrm{Mg}, 90 \\
\mathrm{mg} / \mathrm{kg} \text { of } \mathrm{Mn}, 0.40 \% \mathrm{~S}, 0.02 \% \mathrm{Se}, 125 \mathrm{mg} / \mathrm{kg} \text { of } \mathrm{Zn} \text {. } \\
{ }^{2} \text { Provided per kilogram of MR (DM basis), 55,000 IU vitamin A, 5,600 IU vitamin D, } 350 \mathrm{IU} \text { vitamin E, } 15 \\
\text { mg/kg of vitamin B1, } 35 \mathrm{mg} / \mathrm{kg} \text { of vitamin B2, } 25 \mathrm{mg} / \mathrm{kg} \text { of vitamin B6, } 100 \mathrm{mg} / \mathrm{kg} \text { of vitamin C, } 75 \mathrm{mg} / \mathrm{kg} \text { of } \\
\text { pantothenate. }\end{array}$} \\
\hline
\end{tabular}

Table (2). Chemical analysis of different feedstuffs and calculated chemical composition of the experimental rations.

\begin{tabular}{lcccccc}
\hline Item & DM & CP & EE & CF & NFE & Ash \\
\hline CFM1 & 88.78 & 15.97 & 2.93 & 6.39 & 67.17 & 7.54 \\
CFM2 & 88.69 & 14.06 & 2.98 & 7.74 & 66.67 & 8.55 \\
Berssem hay & 87.83 & 12.21 & 1.49 & 27.22 & 46.35 & 12.73 \\
Rice Straw & 89.17 & 3.39 & 1.76 & 35.83 & 37.20 & 19.82 \\
Molasses & 25.11 & 4.34 & 0.11 & - & 85.71 & 9.84 \\
Corn & 89.35 & 8.01 & 2.85 & 2.45 & 85.01 & 1.68 \\
Wheat bran & 88.19 & 14.82 & 4.27 & 12.43 & 61.78 & 6.70 \\
Rice bran extracted & 87.54 & 12.31 & 13.55 & 11.71 & 50.57 & 11.86 \\
Soybean meal & 89.20 & 43.86 & 1.73 & 4.21 & 43.60 & 6.60 \\
Rations1 (1 $1^{\text {st }}$ period) & 88.57 & 14.41 & 2.52 & 13.06 & 60.56 & 9.45 \\
Rations2 (2 ${ }^{\text {nd }}$ period) & 88.55 & 12.00 & 2.31 & 16.61 & 57.81 & 11.27 \\
\hline
\end{tabular}

\section{RESULTS AND DISCUSSION}

Chemical composition of different feedstuffs and calculated chemical composition of the experimental rations are given in Table 2 . On the $2^{\text {nd }}$ experimental treatments, all young calves groups were fed rations $1(14.41 \% \mathrm{CP}$ and $13.06 \% \mathrm{CF})$ contained on CFM1 (16\% CP and TDN $70 \%)$, berseem hay and rice straw (70: $25: 5 \%)$ from weaning weight to $150 \mathrm{~kg}$ of live body weight ( $1^{\text {st }}$ period) and fed rations 2 $(12.0 \% \mathrm{CP}$ and $16.61 \% \mathrm{CF})$ contained other formula CFM2 (14\% CP and TDN 65\%), berseem hay and rice straw (60: $25: 15 \%)$ from $150 \mathrm{~kg}$ to $250 \mathrm{~kg}$ of live body weight ( $2^{\text {nd }}$ period).

\section{Feed Intake:}

Data presented in Table (3) indicated that during the $1^{\text {st }}$ period at post-weaning, daily feed intake expressed as DM and TDN was significant higher with G3 than those of other groups (G1) or (G2), being the lowest one was recorded with (G1) group. This may be due to that calves of G3originated on WCM plus 50\% LM and consequently thisled torapidin the development of the rumen in comparison of the G1 or G2.Concerning CP intake G3 group was higher than the other ones, with no significant differences among them. A pronounced increase in solid feed consumption was noticed in G3 groups during weaning and within the $1^{\text {st }}$ period of post-weaning. Feed consumption as DM, TDN and CPby calves fed on all treatments increased with advancing in their age. Lee, et al., (2009) reported that DMI from both solid 


\section{Shahin et al.}

and liquid feeds was not affected by the treatments (whole milk or milk replacer) during the pre and post weaning periods. Concerning, feed conversion, expressed as $\mathrm{kg}$ DM, TDN and CP per kg gain during the $1^{\text {st }}$ period, it could be noticed that improve of feed conversion was recorded for G3 group $(\mathrm{P}<0.05)$ compared with other groups. This might be due to the LM was formulated to provide different plant concentrates and consequently thisled to rapid development of the rumen and enhanced the activity of various microorganisms which can be reflected on more solid feed intake in G3 calves during postweaning period. These results seem to agree with those of Lee, et al. (2009) and Mona, et al. (2014). While, the lowest feed conversion was recorded for $(\mathrm{G} 2)$ ration. This may be due to the differences in daily gain in this period, which was lower for G2. Also data in Table (3) indicated that during the $2^{\text {nd }}$ period, daily feed intake expressed as $\mathrm{kg} \mathrm{DM}$, TDN and CP and feed conversion, expressed as $\mathrm{kg} \mathrm{DM}$, TDN and CP per kg gain for calves in all groups were similar.The values of daily DMI presented here are within the range reported by El-Basiony (1994) being 5.25- $6.25 \mathrm{~kg}$ for weaned buffalo calves up to 15 mo. old .These may be due to that calves in all groups fed nearly similar amounts of rations and contained the same ingredients with similar proportion with similar rate of rumen development and completeness. These results are in good agreement with the findings of Elready (2006) and Lee, et al. (2009).

Table (3). Daily feed intake and feed conversion during the two experimental periods by calves.

\begin{tabular}{|c|c|c|c|c|c|c|}
\hline \multirow[t]{2}{*}{ Item } & \multicolumn{3}{|c|}{ First period } & \multicolumn{3}{|c|}{ Second period } \\
\hline & G1 & $\mathrm{G} 2$ & G3 & G1 & $\mathrm{G} 2$ & G3 \\
\hline \multicolumn{7}{|l|}{ Av. Daily feed intake, $\mathrm{kg}$ (as DM) } \\
\hline DM & $4.16^{c}$ & $4.56^{\mathrm{b}}$ & $4.84^{\mathrm{a}}$ & 6.25 & 6.22 & 6.35 \\
\hline TDN & $2.61^{\mathrm{b}}$ & $2.68^{\mathrm{b}}$ & $2.83^{\mathrm{a}}$ & 3.30 & 3.35 & 3.36 \\
\hline $\mathrm{CP}$ & 0.60 & 0.58 & 0.61 & 0.65 & 0.64 & 0.65 \\
\hline \multicolumn{7}{|l|}{ Feed conversion, $\mathrm{kg} / \mathrm{kg}$ gain } \\
\hline DM & $6.40^{\mathrm{b}}$ & $7.94^{\mathrm{a}}$ & $6.34^{\mathrm{b}}$ & 8.02 & 8.17 & 8.08 \\
\hline TDN & $3.99^{\mathrm{b}}$ & $4.67^{\mathrm{a}}$ & $3.7^{\mathrm{c}}$ & 4.24 & 4.40 & 4.27 \\
\hline $\mathrm{CP}$ & $0.92^{\mathrm{b}}$ & $1.01^{\mathrm{a}}$ & $0.80^{\mathrm{c}}$ & 0.83 & 0.84 & 0.83 \\
\hline 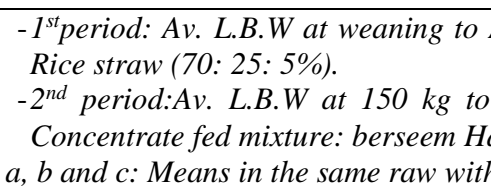 & $\begin{array}{l}\text { L.B. } \\
\text { Rice st } \\
\text { ferent }\end{array}$ & $\begin{array}{l}50 \mathrm{~kg} \\
\text { O: } 25 \text { : } \\
\text { cripts }\end{array}$ & centr & $\begin{array}{l}\text { mixtur } \\
\text { 0.05). }\end{array}$ & starter & $\begin{array}{l}\text { eem hay: } \\
N 65 \% \text {; }\end{array}$ \\
\hline
\end{tabular}

\section{Nutrients Digestibility:}

During the first period at post-weaning, data of Table (4) showed clearly that animals in G3or G1 recorded significant higher $(\mathrm{P}<0.05)$ digestibility values of $\mathrm{DM}$ and $\mathrm{CP}$ than those of $\mathrm{G} 2$. This may be due to the differences in feeding system during pre-weaning period, where treated animal groups given different suckling systems. While those fed in G3 or (G2) recorded higher CF digestibility than those in (G1). This is probably due to that animals in G3and G2 received LM and solid feed and therefore increased of CF\% content, being assistance of rapid development of the rumen. Additionally, calves received solid feeds at the second week of calving enhanced progressively its acceptability to the solid feeds offered during the whole suckling periods. However differences were not significant $(\mathrm{P}<0.05)$ for EE and NFE digestibility in among treatments. Concerning feeding values which expressed as TDN and DCP, it could be noticed that animals in G3 or G1 recorded higher than those of G2 with no significant difference among them. This may be due to the similar rations which contained the same proportion of feed ingredients during the first period at post-weaning.

Concerning the digestibility coefficients and feeding values of experimental rations during the second period at post-weaning are shown in in Table (4). Data showed that digestibility coefficients of all nutrients such as DM, CP, CF, EE, and NFE of experimental rations were nearly similar. Also, feeding values expressed as TDN and DCP for all rations had the same trend of digestibility coefficients of all nutrients illustrated above with insignificant differences among the experimental rations. This may be attributed to using similar ration contained the same proportion of feed ingredients and chemical composition of rations for all groups during the first period at post-weaning. These results are in good agreement with the findings of Elready (2006), Lee, et al. (2009) and Bhatti et al. (2012). 
Egyptian J. Nutrition and Feeds (2015)

Table (4). Effect of dietary treatments on nutrients digestibility during $1^{\text {st }}$ and $2^{\text {nd }}$ periods.

\begin{tabular}{|c|c|c|c|c|c|c|c|c|}
\hline & \multicolumn{4}{|c|}{ First period } & \multicolumn{4}{|c|}{ Second period } \\
\hline & G1 & G2 & G3 & S.E & G1 & G2 & G3 & S.E \\
\hline $\mathrm{DM}$ & $70.85^{\mathrm{a}}$ & $67.14^{\mathrm{b}}$ & $73.01^{\mathrm{a}}$ & 0.13 & 68.29 & 69.12 & 68.83 & 0.38 \\
\hline $\mathrm{CP}$ & $67.41^{\mathrm{a}}$ & $63.34^{\mathrm{b}}$ & $68.75^{a}$ & 0.41 & 66.95 & 66.48 & 67.29 & 0.54 \\
\hline $\mathrm{CF}$ & $54.24^{\mathrm{b}}$ & $56.83^{\mathrm{a}}$ & $57.26^{\mathrm{a}}$ & 1.01 & 57.24 & 56.91 & 57.60 & 0.68 \\
\hline $\mathrm{EE}$ & 70.49 & 69.10 & 70.32 & 0.42 & 72.44 & 71.81 & 72.88 & 0.61 \\
\hline NFE & 71.37 & 70.89 & 71.44 & 0.36 & 71.58 & 70.75 & 72.22 & 0.66 \\
\hline feeding & Values $\%$ & & & & & & & \\
\hline TDN & 63.99 & 63.54 & 64.69 & 1.57 & 62.69 & 62.06 & 63.18 & 1.42 \\
\hline DCP & 9.71 & 9.13 & 9.91 & 0.24 & 8.03 & 7.98 & 8.07 & 0.33 \\
\hline \multicolumn{9}{|c|}{ 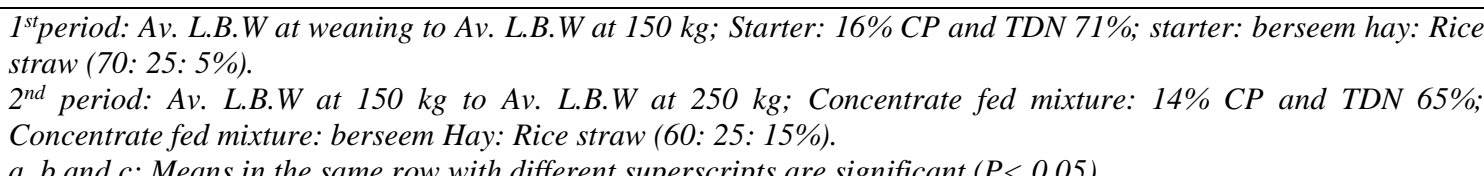 } \\
\hline
\end{tabular}

\section{Productive performance:}

Data of live body weight, total gain, daily gain and age during the first period at post-weaning are presented in (Table 5), it showed that live body weight was nearly similar among treatments, with no significant differences. On the other hand, G2 showed the longest period at age during the first period (196 days), followed by G1, (168 days) days and G3 recorded the shortest period at weaning age (161 days) $(\mathrm{P}<0.05)$. These might be due to the lowest intake of $\mathrm{CP}$ and lowest nutrients digestibility and feeding values (TDN and DCP) with G2 compared with those of other treatmentsas shown in Tables (3 and 4). On the other hand, results obtained indicated that the highest values $(\mathrm{P}<0.05)$ of total gain and daily gain were recorded for G3 ration compared with other treatments, while the lowest one was recorded for G1respecting total gain and for G2 for daily gain.

Data in Table (5) indicated that live body weight and daily gain during the second period at postweaning were nearly similar among all groups. Also, calves on G3 fed diet containing (50\% LM+50\% whole cow milk) during pre-weaning showed the shortest period of age at second period, while the animals fed G1 showed that the highest $(\mathrm{P}<0.05)$ of age at second period.The values of total gain was significantly the highest with G3 over the first period but G1 had the highest value during the second period. Generally, average total and daily gain during whole experimental periods (at first period and second period) were nearly similar among experimental groups. This may be attributed to using unified ration that contained the same proportion of feed ingredients and chemical composition of rations for all groups during the first period of post-weaning. These results are in a good agreement with the findings of Elready (2006), Lee, et al. (2009) and Bhatti et al. (2012).

\section{Blood serum parameters:}

Results of concentrations of plasma total protein, albumin, globulin, urea, calcium and inorg. Phos. did not significantly affected by dietary treatments used in this period. Moreover these diets were balanced in energy and protein levels for these animals which reflected on their health condition and normal performances of all animal groups.

Generally, results in Table (6) during the first and second periods showed, slightly higher total protein and urea concentration in blood with calves fed G1 compared with the other groups. Such results may be due to greater crude protein intake by the former group than the later ones, (Table 3). Increased concentration of blood urea with advancing age over first and second periods indicated a normal physiological fuel shift with the initiation of rumen fermentation and functions (Khan et al., 2007c and 2008). However, urea concentrations in calves fed different treatments are within the normal range that recorded by (Abd El-Aal, 2000 and Hammon et al., 2002). 
Table (5). Growth performance of calves fed different experimental rations at post-weaning.

\begin{tabular}{|c|c|c|c|}
\hline \multirow[t]{2}{*}{ Item } & \multicolumn{3}{|c|}{ Groups } \\
\hline & G1 & $\mathrm{G} 2$ & G3 \\
\hline Initial body weight (at weaning), $\mathrm{kg}$ & $100.51^{\mathrm{a}} \pm 0.72$ & $98.16^{\mathrm{a}} \pm 0.95$ & $92.63^{\mathrm{b}} \pm 0.48$ \\
\hline Weight at first period, $\mathrm{kg}$ & $146.25 \pm 12.23$ & $150.38 \pm 15.17$ & $151.38 \pm 14.6$ \\
\hline Weight at second period, $\mathrm{kg}$ & $252.25 \pm 17.43$ & $248.50 \pm 19.48$ & $250.0 \pm 15.81$ \\
\hline Weaning age, days & $98^{\mathrm{b}}$ & $105^{\mathrm{a}}$ & $84^{\mathrm{c}}$ \\
\hline Age at first period, days & $168^{\mathrm{b}}$ & $196^{\mathrm{a}}$ & $161^{\mathrm{b}}$ \\
\hline Age at second period, days & $304^{\mathrm{b}}$ & $325^{\mathrm{a}}$ & $287^{\mathrm{c}}$ \\
\hline \multicolumn{4}{|l|}{ Total gain, $\mathrm{kg}$} \\
\hline at first period & $45.74^{\mathrm{c}} \pm 1.24$ & $52.22^{\mathrm{b}} \pm 2.89$ & $58.75^{\mathrm{a}} \pm 2.22$ \\
\hline at second period & $106.0^{\mathrm{a}} \pm 2.38$ & $98.12^{\mathrm{b}} \pm 3.11$ & $99.0^{\mathrm{b}} \pm 2.61$ \\
\hline Total periods & $151.74 \pm 2.02$ & $150.34 \pm 3.55$ & $157.37 \pm 3.41$ \\
\hline \multicolumn{4}{|l|}{$\mathrm{ADG}, \mathrm{kg}$} \\
\hline at first period & $0.653^{\mathrm{b}} \pm 0.04$ & $0.574^{\mathrm{c}} \pm 0.08$ & $0.763^{\mathrm{a}} \pm 0.04$ \\
\hline at second period & $0.779 \pm 0.11$ & $0.761 \pm 0.09$ & $0.786 \pm 0.09$ \\
\hline Total periods & $0.737^{\mathrm{a}} \pm 0.08$ & $0.683^{\mathrm{b}} \pm 0.08$ & $0.775^{\mathrm{a}} \pm 007$ \\
\hline $\begin{array}{l}-1^{\text {st }} \text { period: Av. L.B.W at weaning to } \\
\text { Rice straw (70: } 25: 5 \%) \text {. } \\
-2^{\text {nd }} \text { period: Av. L.B.W at } 150 \mathrm{~kg} \mathrm{t} \\
\text { Concentrate fed mixture: berseem H. }\end{array}$ & $\begin{array}{l}\text { W at } 150 \mathrm{~kg} ; \mathrm{S} \\
\text { B.W at } 250 \mathrm{~kg} \\
\text { traw }(60: 25: 15\end{array}$ & $\begin{array}{l}6 \% \mathrm{CP} \text { and TDN } 7 \\
\text { trate fed mixture: }\end{array}$ & $\begin{array}{l}\text { ter: berseem hay: } \\
\text { and TDN 65\%; }\end{array}$ \\
\hline
\end{tabular}

Table (6). Some blood serum parameters of growing buffalo calves fed the experimental diets postweaning.

\begin{tabular}{|c|c|c|c|c|c|c|c|c|}
\hline \multirow[t]{2}{*}{ Item } & \multicolumn{4}{|c|}{ First period } & \multicolumn{4}{|c|}{ Second period } \\
\hline & G1 & $\mathrm{G} 2$ & G3 & S.E & G1 & $\mathrm{G} 2$ & G3 & S.E \\
\hline Total protein, $\mathrm{g} / \mathrm{dI}$ & 6.11 & 5.67 & 5.75 & 0.21 & 6.44 & 6.11 & 6.35 & 0.17 \\
\hline Albumin, $\quad \mathrm{g} / \mathrm{dI}$ & 3.13 & 3.01 & 3.04 & 0.37 & 3.38 & 3.07 & 3.24 & 0.27 \\
\hline Globulin, & 2.90 & 2.74 & 2.63 & 0.21 & 3.06 & 3.04 & 3.11 & 0.22 \\
\hline $\mathrm{A} / \mathrm{G}$ ratio & 1.08 & 1.10 & 1.16 & - & 1.07 & 1.01 & 1.04 & - \\
\hline Urea, & 30.83 & 29.52 & 30.11 & 3.11 & 36.17 & 33.82 & 35.46 & 3.27 \\
\hline Calcium, & 10.79 & 10.72 & 10.61 & 0.61 & 10.69 & 10.60 & 10.59 & 0.91 \\
\hline *Inorg.Phos., mg/dI & 5.61 & 5.52 & 5.46 & 0.19 & 5.70 & 5.68 & 5.60 & 0.33 \\
\hline
\end{tabular}

Results of concentrations of blood total protein, albumin, globulin, urea, calcium and inorganic phosphorus in this study are within the same range that obtained by many authors (Yossef, 1992; ElAshry et al., 1994; Al-Metwally, 1994; Abd El-Aal, 2000 and Khan et al., 2007a,c).

\section{Economic efficiency:}

Data obtained from weaning till the end of the experimental period are recorded as one period to study the growth performances, feed intake and conversion and economic efficiency, as affected by substituting buffalo milk or different level of cow milk + milk replacer during pre-weaning period Table (7). Results indicated that the higher expensive daily feeding cost (LE/ head) was recorded for group G3 or G1, compared with G2. While, price of daily weight gain, LE, was significant higher with G1 and G3 than that for G2 group. These results might be due to the highest values of the daily gain of calves fed G3 and these fed G1.

The same trend was observed with the relative return and economic efficiency, where the best relative return and economic efficiency were obtained by calves fed G3 (19.49 and 102.26\%) followed those G1 (19.06 and 100\%), while those of G2 corresponded the lowest (16.44 and 86.25), with significant differences $(\mathrm{P}<0.05)$. These findings are in agreement with the results of Al-Metwally (1994); Abd El-Aal (2000) and Lee, et al. (2009). 
Table (7). Economical efficiency of buffalo calves due to the carry-over effect of pre-weaning dietary treatments and post-weaning feeding.

\begin{tabular}{|c|c|c|c|}
\hline \multirow[t]{2}{*}{ Item } & \multicolumn{3}{|c|}{ Groups } \\
\hline & G1 & $\mathrm{G} 2$ & G3 \\
\hline Total feed intake, $\mathrm{kg}$ & 5.64 & 5.53 & 5.78 \\
\hline DM & 3.07 & 3.07 & 3.16 \\
\hline TDN & 0.633 & 0.616 & 0.636 \\
\hline \multicolumn{4}{|l|}{$\mathrm{CP}$} \\
\hline Feed conversion, $\mathrm{kg} / \mathrm{kg}$ gain & $7.65^{b}$ & $8.10^{\mathrm{a}}$ & $7.46^{\mathrm{b}}$ \\
\hline $\mathrm{DM}$ & $4.17^{\mathrm{b}}$ & $4.50^{\mathrm{a}}$ & $4.10^{\mathrm{b}}$ \\
\hline TDN & $0.859^{\mathrm{b}}$ & $0.902^{\mathrm{a}}$ & $0.821^{\mathrm{b}}$ \\
\hline \multicolumn{4}{|l|}{$\mathrm{CP}$} \\
\hline Economic efficiency, LE/h/d. & $28.77^{\mathrm{a}}$ & $25.95^{\mathrm{b}}$ & $29.45^{\mathrm{a}}$ \\
\hline Price of daily weight gain, $\mathrm{LE}^{1}$ & 9.71 & 9.51 & 9.96 \\
\hline Daily feeding cost, $\quad \mathrm{LE}^{2} /$ head & $19.06^{\mathrm{a}}$ & $16.44^{\mathrm{b}}$ & $19.49^{\mathrm{a}}$ \\
\hline Return, LE & 100 & 86.25 & 102.26 \\
\hline \multicolumn{4}{|l|}{ Economic efficiency $^{* *}$} \\
\hline \multicolumn{4}{|c|}{ 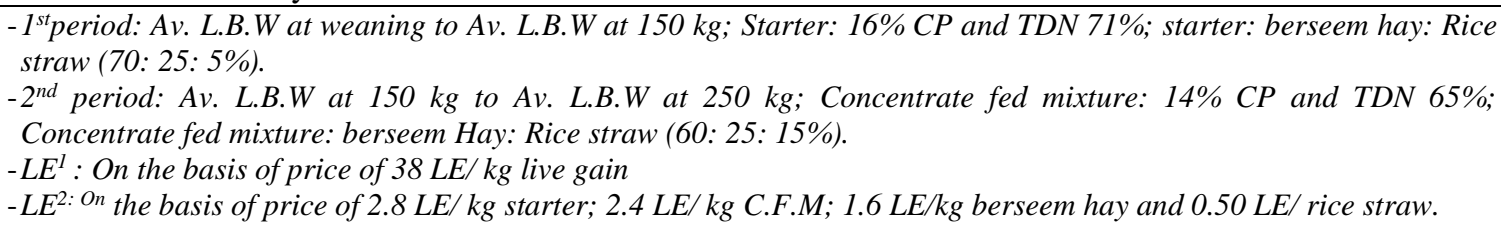 } \\
\hline
\end{tabular}

\section{CONCLUSIONS}

Usingmilk replacer at a rate of 50\% in combination with 50\% whole cow milkin replacing to the whole buffalo milk during pre-weaning period could be improved productive performance and economic efficiency for buffalo calves compared with the whole Buffalo milk during pre-weaning period. This may help farmers to keep up and care of suckling buffalo calves and not sell them and such regime could help to alleviate the problem of milk and beef shortage in Egypt.

\section{REFERENCES}

Abdalla, H.O.; D.G. Fox and M.L. Thonney (1988). Compensatory gain by Holstein calves after underfeeding protein. J. Anim. Sci., 66:2687-2695.

Abd El-Aal, S.A.E. (2000). Nutritional studies on raising suckling calves. Ph.D. Thesis, Fac. Of Agric., Ain Shams Univ., Egypt.

Al-Metwally, A.A. (1994). Puberty and related phenomena in male Egyptian buffalo calves and its relation to plane of nutrition. M.Sc. Thesis, Fac. Of Agric. AinShama. Univ., Egypt.

Ansotegui, R.P. (1986). Chemical composition and rumen digesta kinetics of diets selected and influence of milk intake on forage intake by suckling calves grazing native range. PhD. Dissertation. New Mexico State Univ., Las Cruces.

A.O.A.C. (1995). Official Methods of Analysis. 15th ed. Association of Official Analytical Chemists, Arlington, Virginiall, USA.

Armstrong W.D. and C.W. Carr (1964). Physiological Chemistry $3^{\text {rd }}$ ed. P 75 Burges Publishing co. Minneapolis Minnesota.

Baker, R.D. and J.M. Barker (1978). Milk-fed calves. 4. The effect of herbage allowance and milk intake upon herbage intake and performance of grazing calves. J. Agric. Sci., 90:31-38.

Bhatti, S.A.; A. Ali; H. Nawaz; D. McGill; M. Sarwar; M. Afzal; M.S. Khan; Ehsanullah, M.A. Amer; R. Bush; P.C. Wynnand and H.M. Warriach (2012). Effect of pre-weaning feeding regimens on postweaning growth performance of Sahiwal calves. Journal of Applied, 6 (8):1231.

Brown, E.G.; M.J. Vandehaar; K.M. Daniels; J.S. Liesman; L.T. Chapin; D.H. Heisler and M.S. Weber Nielsen (2005). Effects of increasing energy and protein intake on body growth and carcass composition of heifer calves. J. Dairy Sci., 88:585-594.

Doumas, B.; W. Watson and H. Biggs (1971). Albumin standars measurement of serum with bromocresol green. Clinical Chemistry Acta, 31:37. 


\section{Shahin et al.}

Duncan (1955). Multiple range and multiple F test. Biometric, 11: 1-42.

El-Ashry, M.A.; A.Z. El-Basiony; A.M. El-Serafy and M.F. Sadek (1994). Probiotic (L.B) in buffalo heifers rations: 2- Effect on some blood parameters. J. Anim. Prod., 31:15.

El-Basiony, A.Z. (1994). Performance of growing lambs and buffalo calves given flavomycin as a feed supplement. Annual Agric. Sci., Moshtohor, 32: 1511.

Elready, K.F.E.A.L. (2006). Rearing buffalo calves under different feeding systems. Ph.D. Thesis, Faculty of Agric., Kafr El-Sheikh Tanta Univ., Egypt.

FAO (1998). Production year book, Vol. 52 FAO Publ., Rome. Italy, pp 35.

Hammon, H.M.; G. Schiessler; A. Nussbaum and J.W. Blum (2002). Feed intake patterns, growth performance, and metabolic and endocrine traits in calves fed unlimited amounts of colostrum and milk by automate, starting in the neonatal period. J. Dairy Sci., 85:3352.

Henry R.J. (1964). Clinical chemistry Harber and Row publishers, New york p.181.

Kearl, L.C. (1982). Nutrients allowance of ruminants in developing countries. International Feedstuffs Institute Utah Agricultural Experiment Station Utah State University, Logan Utah December.

Khan, M.A.; H.J. Lee; W.S. Lee; H.S. Kim; S.B. Kim; K.S. Ki; J.K. Ha; H.G. Lee and Y.J. Choi (2007a). Pre-and post-weaning performance of Holstein female calves fed milk through step-down and conventional methods. J. Dairy Sci., 90:876.

Khan, M.A.; H.J. Lee; W.S. Lee; H.S. Kim; S.B. Kim; K.S. Ki; S.J. Park; J.K. Ha and Y.J. Choi (2007c). Starch source evaluation in calf starter: I. Feed consumption, body weight gain, structural growth, and blood metabolites in Holstein calves. J. Dairy Sci., 90:5259.

Khan, M.A.; H.J. Lee; W.S. Lee; H.S. Kim; S.B. Kim; S.B. Park; K.S. Baek; J.K. Ha and Y.J. Choi (2008). Starch source evaluation in calf starter: II. Ruminal parameters, rumen development, nutrients digestibilities and nitrogen utilization in Holstein calves. J. Dairy Sci., 91:1140.

Kuehn, C.S.; D.E. Otterby and J.G. Linn (1994). The effect of dietary energy concentration on calf performance. J. Dairy Sci., 77:2621-2629.

Lee, H.J.; M.A. Khan; W.S. Lee; H.S. Yang; S.B. Kim; K.S. Kim; H.S. Kim; J.K. Ha and Y.J. Choi (2009). Influence of equalizing the composition of milk replacer to that of whole milk on the performance of Holsten calves. J. Anim. Sci., 87:1129.

Lynch, G.P.; T.L. Pike and J. Bond (1978). Nutritional responses of calves fed milk or a milk replacer. J. Dairy Sci., 61:212-220.

Meyer, M.J.; A.V. Capuco; D.A. Ross; L.M. Lintault and M.E. Van Amburgh (2006a). Developmental and nutritional regulation of the prepubertal heifer mammary gland: I. Parenchyma and fat pad mass and composition. J. Dairy Sci., 89:4289-4297.

Meyer, M.J.; A.V. Capuco; D.A. Ross; L.M. Lintault and M.E. Van Amburgh (2006b). Developmental and nutritional regulation of the prepubertal bovine mammary gland: II. Epithelial cell proliferation, parenchymal accretion rate, and allometric growth. J. Dairy Sci., 89:4298-4304.

Moms, C.A. and J.W. Wilton (1976).Influence of body size on the biological efficiency of cows: A review. Can. J. Anim.Sci., 56:613.

Mona E. Farag; S.A. Ebrahim and M.A. Abd EL-latif (2014). Effect of feeding different levels of synthetic liquid milk on the production performance of suckling buffalo calves. 1- At preweaning. Egyptian J. Nutrition and Feeds, 17 (2): 183-192.

Nigm, A.A. (1996). Characterization of the Egyptian buffalo International Symposium on Buffalo Resource and Production System, Anim. Prrod. Res. Inst. Cairo, Egypt 14-17 October. P. 1.

Patton C.J. and S.R. Crouch (1977). Anal. Chem., 49: 464.

SAS (1998). Statistical analysis system SAS user's Guide: Statistics. SAS institute Inc. editors, Cary, N

Saunders W.P. (1970). Fundamental of Clinical Chemistry, Philadlivia.

Totusek, R. and D. Arnett (1965). Estimates of milk production in beef cows. J. Anim. Sci. 24:906. (Abstr.)

Wright, I.A. and A.J.F. Russel (1987). The effect of sward height on beef cow performance and on the relationship between calf milk and herbage intakes. Anim. Prod., 44:363-370.

Wyatt, R.D.; M.B. Gould and R. Totusek (1977). Effects of single vs simulated twin rearing on cow and calf performance. J. Anim. Sci., 45:1409-1414.

Yossef, M.M (1992). Growth pattern of buffalo calves in relation to rumen development and growth promoters' treatment. Ph.D. Thesis, Fac. Of Agric., Cairo. Univ., Egypt. 
تأثير التفذية على مستويات مختلفة من السائل اللبنى الأصطناعي على الأداء الانتاجى لعجول الجاموس

$$
\begin{aligned}
& \text { جمال فاروق شاهين و منى أحمد السيد فرج و صلاح السيد عطية و مجدى عبد الرحمن عيد اللطيف. } \\
& \text { معهُ بحوث الأنتاج الحيوانى - مركز البحوث الزراعية - وزارة الزراعة الاقدى - جيزة - مصر. }
\end{aligned}
$$

أجريت هذة الدراسة بهدف تقيم تأثير أستخدام مستويات مختلفة من بديل الألبان مخلوط مع اللبن البقرى كامل مقارنة مع اللبن

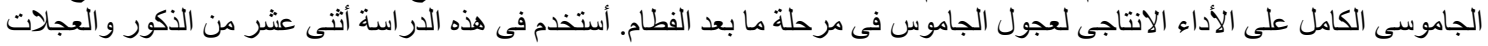

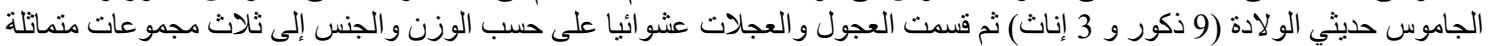

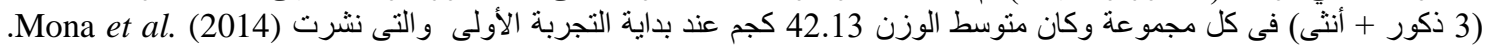

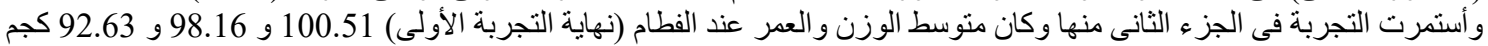

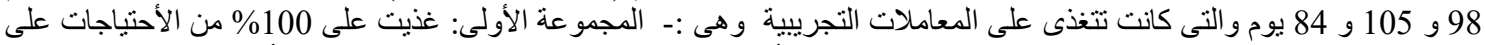

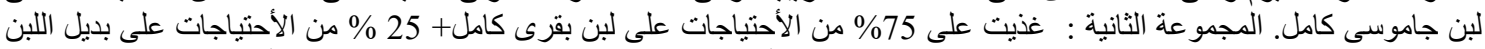

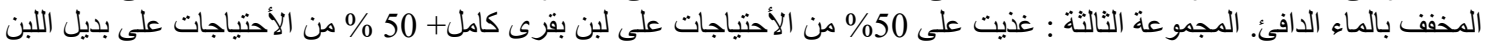

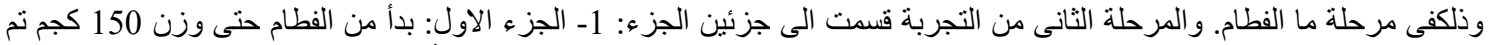

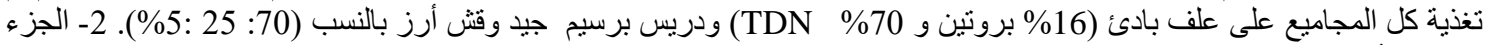

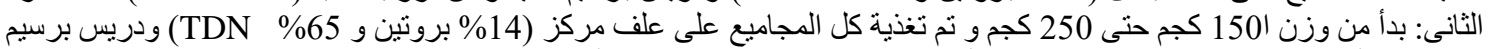
جيد وقش أرز بالنسب (60: 25: 15\%). وأشارت النتائج الى: 1- الجزء الأول من مرحلة ما بعد الفطام (من الفطام حتى وزن برن

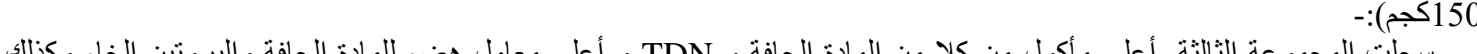
سجلت المجموعة الثالثة أعلى مأكول من كلا من المادة الجافة و TDN و أعلى معامل هضم للمادة الجافة والبروتين الخام وكذلك

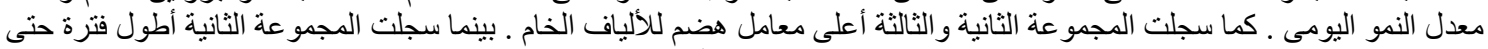

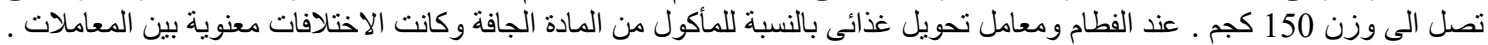

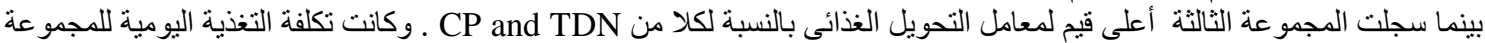

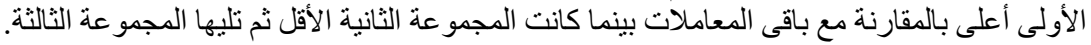

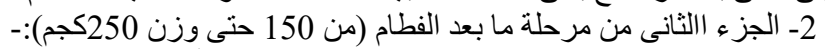

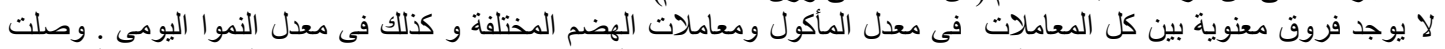

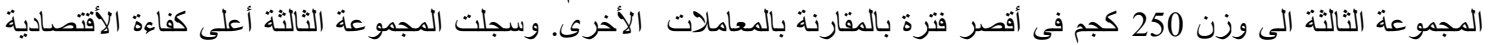

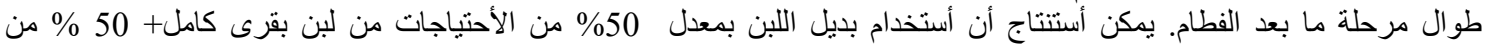

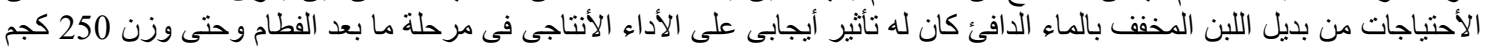
و هذا قد يساعد المربين على الاهتمام والر عاية بعجول الجاموس الرضين الريعة وقد يساعد على تخفيف مشكلة نقص اللبن و و اللحوم بمصر. 